\title{
IRRIGATION ENGINEERING IN SPAIN AND HOW IT HAS CHANGED THE COUNTRY'S LANDSCAPES
}

\author{
José M. García-Asensio ${ }^{1}$, Francisco Ayuga $^{2}$
}

Received 13 June 2016; Accepted 26 October 2016

\begin{abstract}
Irrigation is a rural development technique widely extended in, and affecting the landscape of, areas of Mediterranean climate. In Spain, irrigation accounts for $2 / 3$ of all water use. The country has over 3.5 million ha of irrigated land, some $15 \%$ of all its agricultural land. Valley bottoms and riversides are the landscapes most commonly associated with irrigation in Spain, followed by peninsular coastal and interior plains, basins, hollows and depressions. This paper describes the engineering infrastructures associated with irrigation, the structures involved in water capture, transport, storage and distribution, and water use and drainage in the irrigated lowlands of Spain. It also examines the environmental impact of such water use. Several descriptors are proposed to describe its association with the landscape.
\end{abstract}

Keywords: Landscape, irrigation, water engineering, rural development, Mediterranean, Spain

Resumen: El regadío ha sido una técnica de desarrollo rural ampliamente extendida en los climas mediterráneos determinando sus paisajes. Es el principal usuario del agua en España, su consumo supone 2/3 del total. Con más de 3,5 millones de hectáreas representa cerca del $15 \%$ de la superficie agrícola útil. La principal asociación de tipos de paisajes bajo riego son vegas y riberas, seguida de llanos litorales peninsulares e interiores, campiñas y cuencas, hoyas y depresiones. Presentamos las principales infraestructuras de ingeniería, con obras de captación, trasporte, almacenamiento, distribución, aplicación a las tierras bajo riego y drenaje. Revisamos su consideración en la evaluación de impacto ambiental. Y proponemos diversos descriptores sobre su consideración en el paisaje.

\section{Introduction}

Irrigation engineering - a facet of water engineering - is a tool at the service of rural development. In areas of Mediterranean climate, where agriculture accounts for $2 / 3$ of all water use, irrigation engineering is of particular importance. The hot summers of Spain, which coincide with the period of minimum rainfall, leave no doubt as to the importance of water. Summer conditions drive a distinction within the landscape between natural vegetation/rainfed agricultural land, and land under irrigation. The management of water resources and

\footnotetext{
1 José María García Asensio, TRAGSA, C/Maldonaldo 58, 28006 Madrid, Spain; e-mail: jgarci36@tragsa.es

2 Prof. Ing. Francisco Ayuga Tellez, PhD., BIPREE research group, Universidad Politécnica de Madrid, Ciudad Universitaria s/n, 280740 Madrid, Spain; e-mail: francisco.ayuga@upm.es
} 
the building of infrastructures related to water capture, transport, storage, distribution and use reflect how water engineers have to "dialogue" with the land in Mediterranean landscapes. The result of that dialogue is often landscape change.

The European Landscape Convention established the need to integrate the landscape into territorial planning policies, and contemplates that each Member State identify its landscapes, analyse their characteristics, determine the pressures and forces that transform them, and make note of those transformations. The Atlas of Spanish Landscapes (Atlas de los Paisajes de España) (Mata \& Sanz, 2003), which contemplates 34 landscape associations, is a prime example of landscape identification and classification. This work contains a series of maps and an analysis of Spanish landscapes that could easily serve as a framework for other regional or local studies. The publication reveals the notable diversity of Spain's landscapes which have formed within a framework of strong ecological and cultural relationships. It describes the trends that alter traditional landscapes and give rise to more modern variants, examines the need for managed interventions that allow the conservation of the country's landscape heritage, and discusses the use of landscape resources.

The identification of Spain's landscapes involved the establishment of a scale of units: 1) the landscape as the basic unit, 2) types of landscape (landscapes of similar natural configuration and territorial history), and 3) associations of types of landscape, which take into account the most evident features of landscape units, their climatic conditions, and most important hydrological characteristics.

Six landscape associations account for nearly $60 \%$ of Spain's total area; these are 'countryside' and 'Mediterranean and Continental mountains and hills' (each accounting for over 11\%), 'interior plains' and 'peniplains and piedmonts' (over 9\% each), and 'moorland', 'mesas', and 'basins, hollows and depressions' (over 7\% each) (García-Asensio \& San Sebastián, 2006).

A dispersion index reflecting the repetition of each type of unit within the total number of units was also calculated. 'Small islands and islets' were eliminated from this analysis given their overly strong presence, which would have distorted the result. Thus, 'Mediterranean and Continental mountains and hills' were found to account for over $13 \%$ of all units, 'basins, 'hollows and depressions' nearly $9 \%$, 'valley bottoms and riversides' and 'countryside' over $6 \%$ each, 'corridors', 'valleys' and 'interior plains' over 5\% each, and 'moorland', 'mesas' and 'Atlantic and Sub-Atlantic mountains and hills' over 4\% each (García-Asensio \& San Sebastián, 2006).

Royal Decree (Real Decreto) 329/2002 approved the National Irrigation Plan (Plan Nacional de Regadíos) (MAPA, 2001), a major instrument in the modernisation, planning and promotion of irrigation in Spain. Studies on the characterisation and classification of irrigated areas by the Spanish Ministry of Agriculture, Food and the Environment report the country to have some 3.5 million ha of irrigated land - some $7 \%$ of the entire nation (García-Asensio \& San Sebastián, 2006).

Some $30 \%$ of irrigated land can be found within 'valley bottoms and riversides', followed by 'peninsular coastal plains' and 'interior plains' (>13\% each), 'countryside' $(<11 \%)$, and 'basins, hollows and depressions' (10\%) (together covering some $80 \%$ of Spain's irrigated surface).

These landscape units share a certain similarity in their relief - they have flat or slightly sloped land (making them open in appearance) - that renders irrigation possible. 'Corridors' and 'Mediterranean and Continental mountains and hills' and 'marshes, deltas and Mediterranean and southern Atlantic coastal sands' account for a further 3-4\% each. 'Valley bottoms and riversides' are the most common landscapes to make use of surface water for irrigation.

The relationship between the landscape under irrigation and the total area occupied by each landscape association indicates the relative prominence of irrigation in each (figure 1). Nearly $70 \%$ of 'valley bottoms and riversides', $50 \%$ of 'peninsular coastal plains' and $40 \%$ of 'marshes, deltas and Mediterranean and southern Atlantic coastal sands' are under irrigation. The landscape character of these units is therefore strongly conditioned by irrigation (GarcíaAsensio \& San Sebastián, 2006). The presence of fresh water from rivers, and salt water from the sea, adds great value to these landscapes. In valley bottoms, the union between irrigation 
and rivers is intimate; rivers provide the deep, fertile soil of floodplains, as well as water at the surface and water extractable via wells. And while the sea provides no water for irrigation unless it is desalinated, it helps create the benign climatic conditions that promote crop growth.

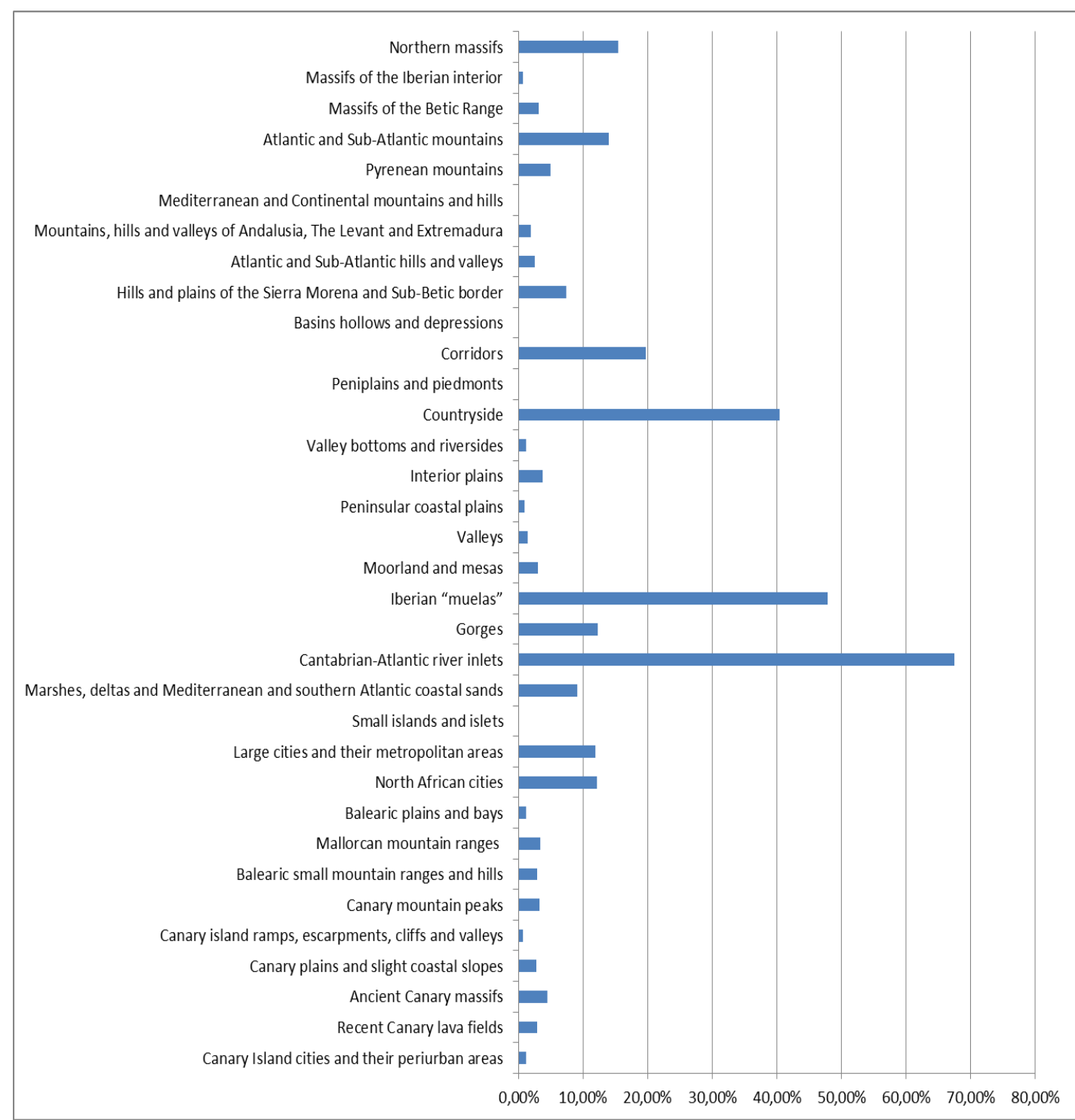

Fig 1. Relationship between landscape under irrigation and total area occupied by each landscape association (\%) (translated from García-Asensio \& San Sebastián, 2006).

Some $10-20 \%$ of 'large cities and their metropolitan areas', 'Canary Island cities and their periurban areas', 'Canary plains and slight coastal slopes', 'interior plains', 'basins, hollows and depressions', 'corridors' and 'countryside' are also under irrigation. When irrigation has to compete with urbanisation, it loses out and falls into decline. This is especially true in metropolitan areas, industrialised valley bottoms, and along coastlines where tourism is important (Díaz-Palacios-Sisternes et al., 2014).

\section{Theoretical background}

The first constructions associated with water management were surely wells. Wells have been found in many primitive settlements, the most ancient being Atlit Yam in Israel (dated to around 6500 BC). Ancient settlements sometimes also contain rustic levers for raising water in pots. Wells have been made throughout history, although the techniques used in their excavation and the holding in place of their walls have improved, as have the methods by which water is raised (Galili et al., 1993). In themselves, these constructions are rarely large enough to influence 
the landscape, although there are a few places where they have given it a particular appearance. Such is the case in some parts of Spain's Castilla La Mancha region.

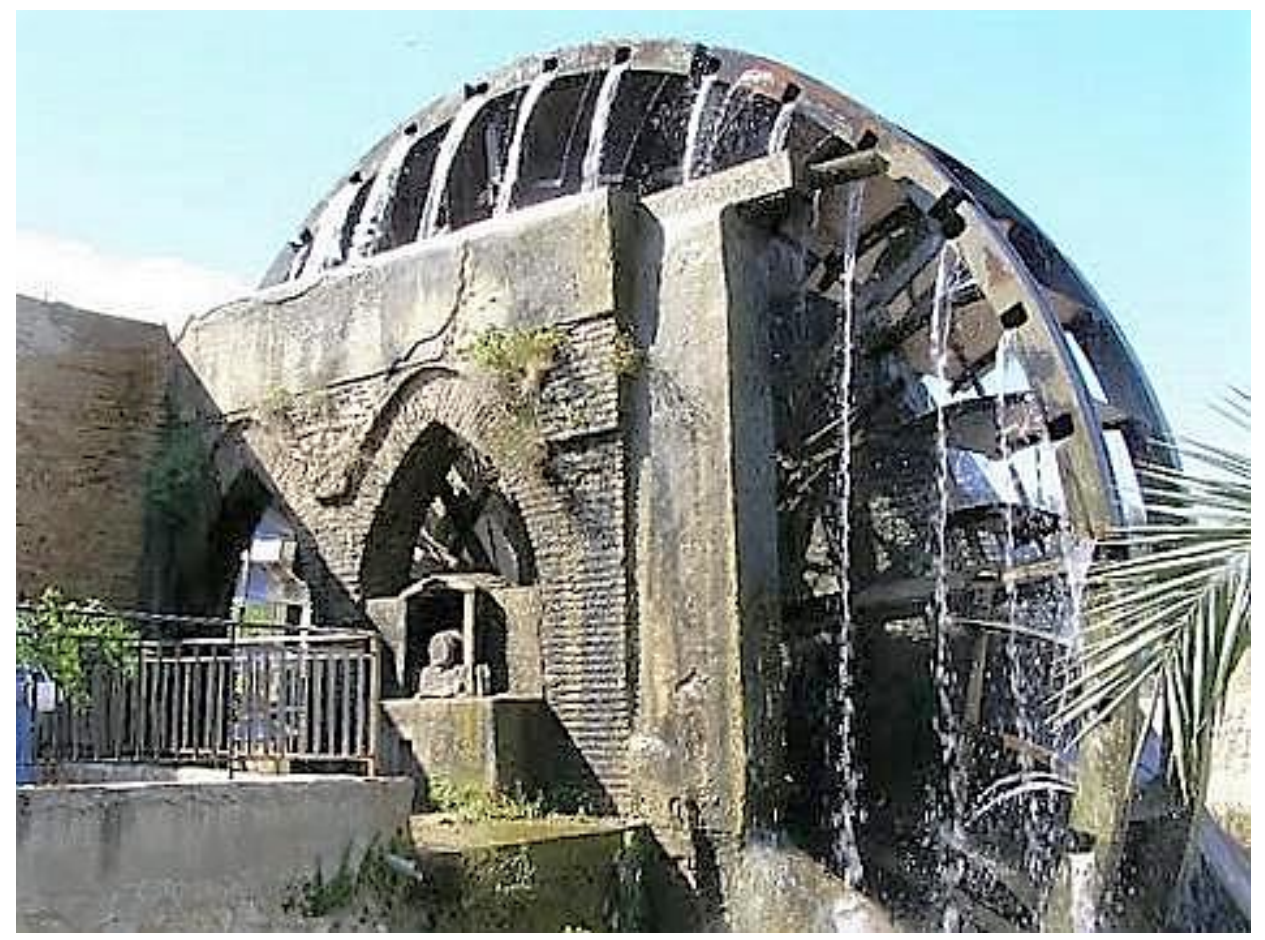

Fig 2. A famous water wheel at Alcantarilla in Murcia

(from https://es.wikipedia.org/wiki/Archivo:Rueda_de_Alcantarilla.jpg

Some constructions associated with wells possess cultural and landscape interest, e.g., water wheels. In Spain, those of the Moorish period are of particular importance. In many cases these constructions characterise the cultural landscape and can achieve great fame. The above image shows the water wheel at Alcantarilla in Murcia (figure 2). Those of the River Guadalquivir, where it passes through Cordoba, or those at the Rueda in Sástago Monastery (Zaragoza) on the River Ebro, also stand out.

Wells often have associated water drainage channels (in Murcia, where they are common, they are known as lumbreras). These channels are simple, excavated systems introduced into Spain following its invasion by the Moors. They are of great cultural interest but have little effect on the landscape (Olmo \& Muñoz, 2004).

The influence of wells on the landscape is not, however, merely visual. The availability of water to different civilisations and cultures, and therefore their ways of forming the landscape, has been of great importance. The irrigated areas around wells, the maximum distance the water can reach, and the division of irrigated land, configure a particular landscape topology.

Larger water engineering constructions associated with irrigation would soon follow the advent of wells. On the banks of the Tigris and Euphrates, the Nile, the Indus, and in the south of Mexico, organised societies began to appear that were capable of capturing and directing water, thus freeing themselves of having to rely on rising river levels to irrigate their crops. The essential elements in these first irrigation systems were canals, channels and dams/reservoirs (Subias et al., 2013).

The first true canals were those now seen at the archaeological site of Choga Mami in the Tigris valley; these are $2 \mathrm{~m}$ wide and date to $4500 \mathrm{BC}$. In Europe, the Greeks and Romans made many canals. They dealt with difficult terrain by constructing aqueducts (that at Segovia is among the largest and best known) and tunnels (such as that at Eupalinos on Samos; over $1 \mathrm{~km}$ long, this was dug in the 4th century BC) (Kamash, 2012). 


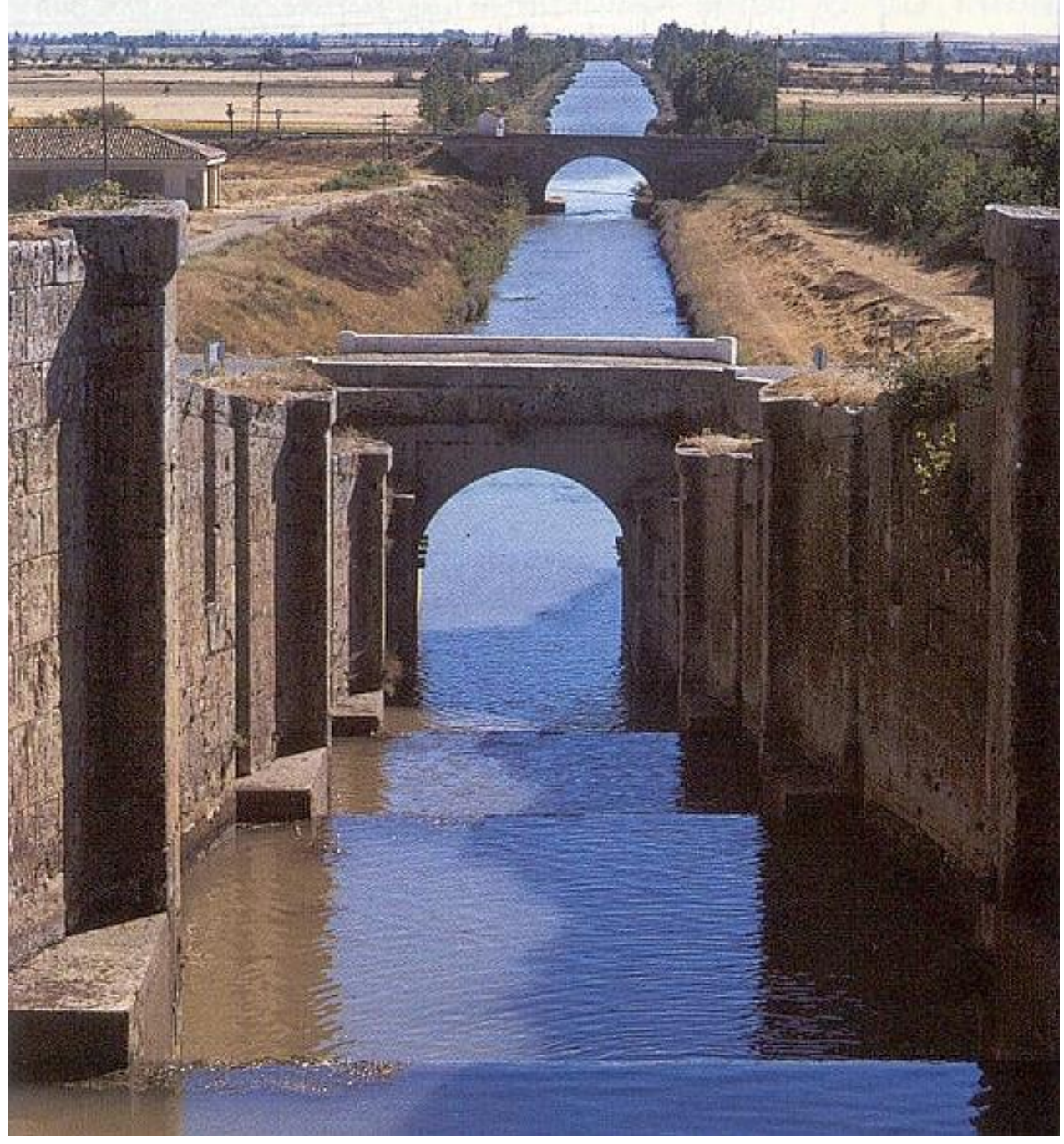

Fig 3. The Castilla Canal (from http://www.chduero.es/).

Over the centuries of the Common Era, canals were built all over Europe for transport, water supply and irrigation (Wilkinson \& Rayne, 2014). Canals (especially large canals) are linear landscape elements of the first order that characterise the views in which they appear. They are associated with an adjacent band of vegetation. In Spain, the Castilla Canal is a good example of a canal with cultural and landscape importance (Helguera et al., 1988) (figure 3). Aqueducts were constructed where needed, especially in Spain given its difficult terrain; the San Telmo aqueduct in Malaga, built in the $18^{\text {th }}$ century provides an interesting example. By the $20^{\text {th }}$ century Spain was home to many large canals that made their mark on large landscapes. The Canal de Monegros, the Tajo-Segura Transfer (the landscape implications of which are not restricted to its effect on the view), and the more modern Navarra Canal, are all good examples.

Irrigation channels are also important. Much more modest in size, but many in number, these had more influence over the landscape than canals. During the Middle Ages, the Moors greatly increased the number of irrigation channels in Spain, especially in the south. Nowadays such channels are usually dug into the earth or are made of prefabricated concrete or plastic materials; rarely are they made of masonry or stone lined. Along with the associated web of paths and drainage channels, they confer a network or fishbone appearance upon irrigated land. Irrigation channels are also commonly lined by vegetation, a consequence of the water that escapes from them, which makes them stand out in the landscape.

Irrigation canals and channels are fed from a well or from a water deposit of some kind, structures that also made early appearances in the history of technology. The great dam of Tehuacán, in Mexico is almost $25 \mathrm{~m}$ high and was constructed around 750 BC - without the knowledge of the wheel or the use of animals to pull loads. The dam and its reservoir were 
accompanied by over $1000 \mathrm{~km}$ of canals and irrigation channels ('tecoatls'). A great dam has also recently been found in Egypt. It was probably used to protect Karnak when the Nile flooded; it may even be older than the Mexican dam (Fahlbusch, 2009).

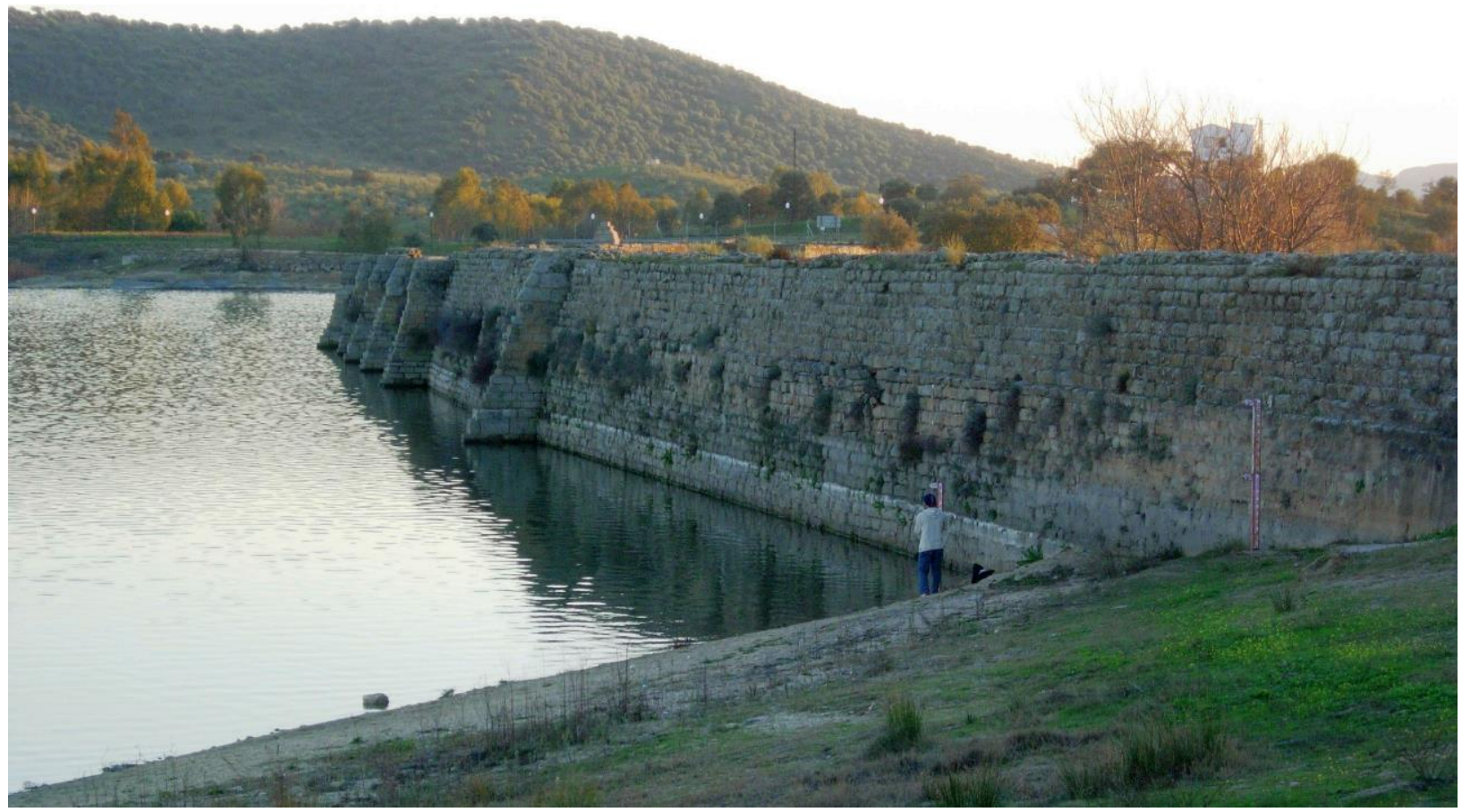

Fig 4. The dam of Proserpina (Mérida) (from the author's archive).

The Romans were also great constructors of dams, and left them all over Europe. Spain is home to some very important Roman dams that have been recovered for modern-day use e.g., at the Cornalvo and Proserpina reservoirs outside Mérida (figure 4). These stone-lined, concrete-walled structures (with used quicklime as an agglomerating agent) store 10 and $6 \mathrm{hm}^{3}$ of water behind them respectively, and are 18 and $21 \mathrm{~m}$ high. At $34 \mathrm{~m}$ high, the largest dam the Romans probably ever built is also in Spain, at Almonacid de la Cuba (Zaragoza). In total, there are 49 Roman dams in Spain (Parra \& Barranco, 2003).

Dam building has gone on ever since, although sizes were always modest until the end of the $19^{\text {th }}$ century. During Medieval times fewer were built, and many have probably been lost due to their poor quality compared to Roman handiwork. The Moors in Spain were more given to the construction of weirs (Hill, 2013) which are discussed later. Today there are over 1500 dams in Spain, nearly all of them constructed in the 20th century. They are very varied in their characteristics, although they have points in common. From the point of view of their influence on the landscape, a small dam of $1 \mathrm{hm}^{3}$ capacity is very different to one with over $100 \mathrm{hm}^{3}$. The level of water at different moments during the year and the type of dam, also have their influence.

Questionnaires have shown (Cañas et al., 2009) that the populations of arid countries appreciate the presence of water bodies, and a full reservoir behind a dam is very similar to a lake. But dams have the drawback that when the water recedes there is a lack of perimeter vegetation - they do not look so good when the water level is low. 


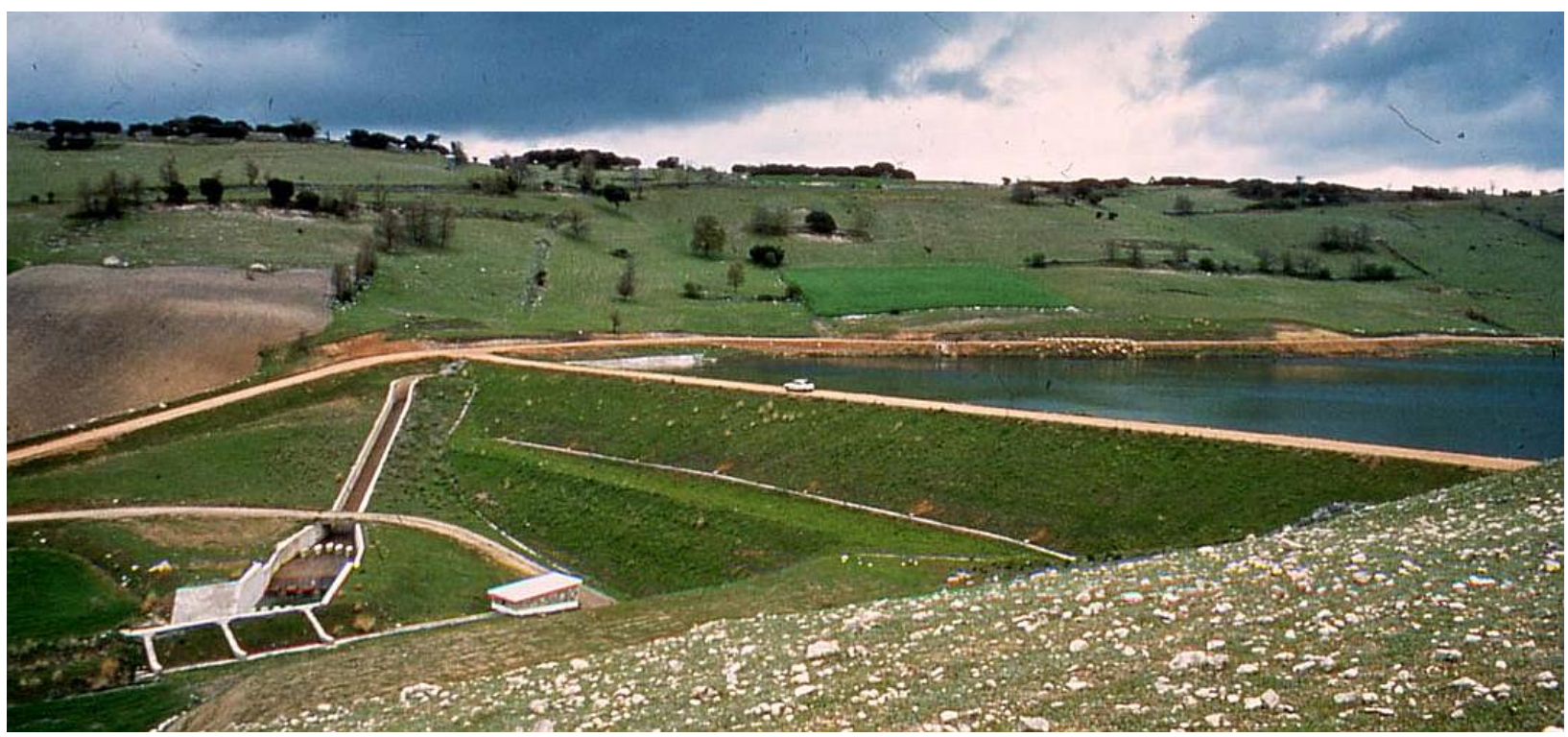

Fig 5. Earth dam slope with vegetation (from the personal archive of R. Dal-Re).

There is also a visual impact when a dam is easily seen. Concrete dams and reservoirs with asphalt or concrete linings have a very anthropic, denaturalising effect on the landscape. Earthen dams, however, especially those carrying vegetation, can integrate into the landscape and even be hard to spot for non-expert eyes (figure 5).

The influence of reservoirs (especially the largest) on the landscape is not limited to their visual impact; they can cause changes in the microclimate and modify the biology of their surroundings. The flooding of areas where animals once passed by or reproduced, the interruption of the migration of salmonids, and the appearance of waterfowl that alter the local ecology, are all classic reservoir problems. Plants too can suffer. Areas may be flooded where threatened species live, and incoming riparian vegetation may displace local species. The so-called cultural landscape can also be upset: churches, bridges, even whole villages may disappear under the water. Some of these problems have been solved as new designs have come into use, but others remain matters of much debate (Everard, 2013).

There is also the problem of what to do when a reservoir reaches the end of its useful life. Erosion and sedimentation can eventually lead to overflows. The water can also suffer eutrophication, becoming coloured with algae and foul smelling. All of these phenomena affect the landscape and its value (Doyle et al., 2003).

Weirs are a different concept. These constructions are probably Medieval in origin and were introduced into Spain by the Moors. Their job is not to stop a river from flowing, but to raise its level so that water can be diverted for irrigation purposes or to drive a mill. Arabic weirs are still visible in many parts of southern and eastern Spain, such as on the River Turia in Valencia or the River Segura in Murcia. Since these times more weirs have been built, normally for irrigation purposes, for diverting water for industrial use, or for providing water to urban centres. From a landscape standpoint they are similar to dams/reservoirs, although the wall has less of a visual impact since it is normally submerged. Weirs come in different sizes, though they are usually smaller than dams and their reservoirs (Cañas, \& Pérez, 2007).

In the Roman Era water was also used as source of energy, giving rise to a number of constructions including water mills and gold mines. 


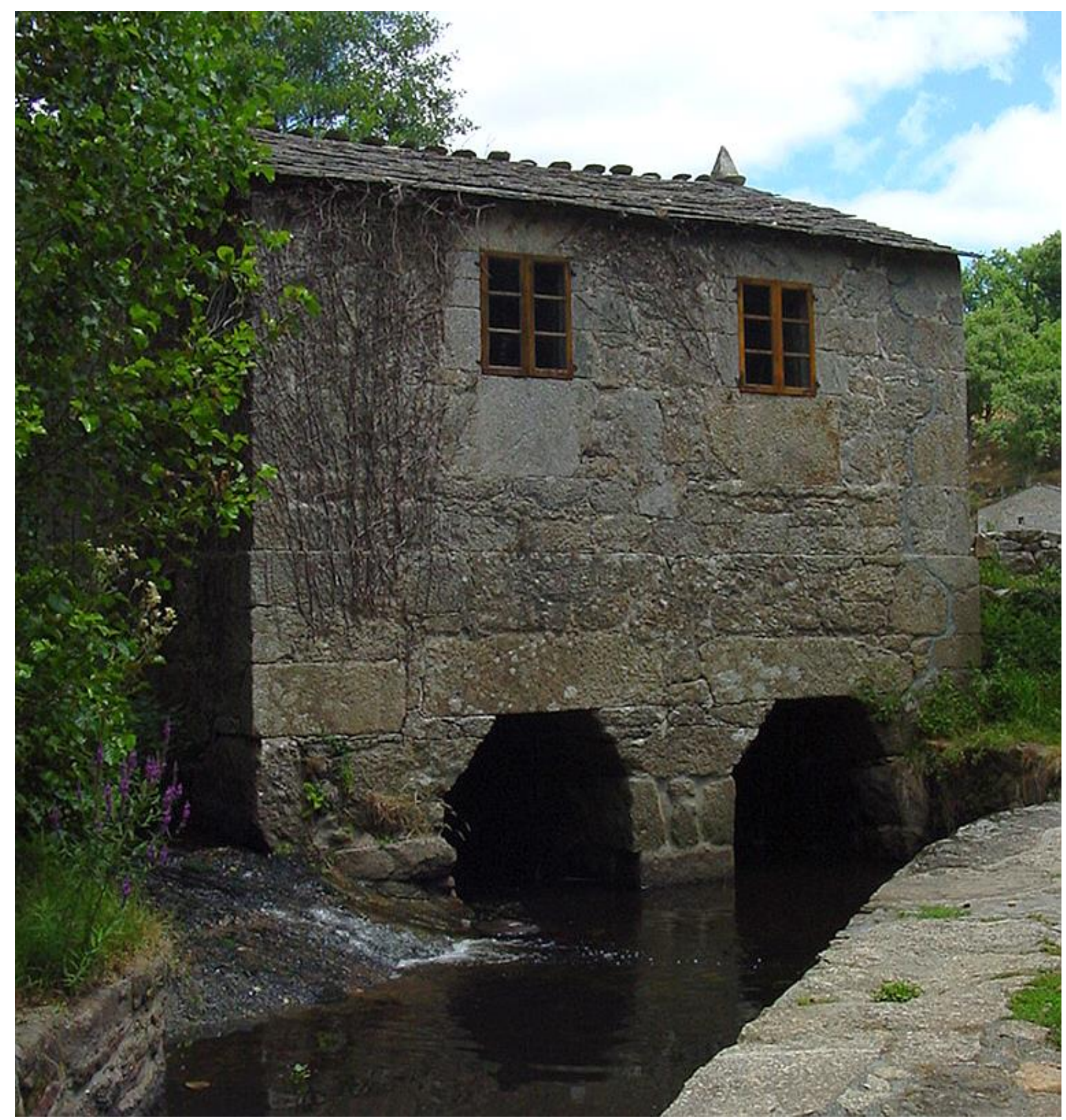

Fig 6. An ancient water mill in Lugo (Spain) (from the author archive).

Water mills became widespread across the Mediterranean during Roman times, although they really increased in number after Christianity was declared the official religion of Rome. As slavery slowly disappeared, mill wheels had to be turned by either animals or hydraulic devices. During the Middle Ages, the control of water mills and the water that moved them became a matter of great economic importance. They were of course used to grind cereals, but also in the production of textiles (as fulling machines), wood (as saw mills), paper, and iron goods (as smithies) (figure 6). In the $18^{\text {th }}$ century, the Royal Factories, which minted coins and made weapons and textiles etc., also operated a number of water mills, including that used by the mint in Segovia. These mills were used well into the 20th century, and although some still function today they usually do so as museum pieces.

Throughout Europe, but especially in the Mediterranean, it is difficult to completely understand riverside landscapes without some knowledge of the purpose, design and history of water mills. They appear all along our riverbanks and are of great landscape interest. Normally they appear in areas of abundant riverside vegetation that runs into their outlines and may even hide them. 
The main building usually reflects the popular culture of the area, and usually has either vertical or horizontal action wheels, channels for directing water towards the water wheel, and a small dam or weir to keep a constant water level throughout the year (Rojas-Sola \& López-García, 2007).

Irrigation is an ancient practice, as old as agriculture. The Neolithic societies of Mesopotamia, Egypt and the Andes sprang up around rivers that could provide water for crops. Some authors attribute the appearance of city states and the first political organisation to the appearance of these irrigating societies.

The establishment of irrigated land has, since ancient times, gone hand in hand with the topographic transformation of the landscape. Testament to this are the reinforced terraces of the Oaxaca Valley in Mexico, which were constructed in Neolithic times, or those of the Incas in Peru or parts of Asia made in the first centuries of our era.

The appearance of earth-moving machines led to much greater topographic changes across entire irrigated areas. Large areas have been levelled, terraced and reinforced, greatly modifying the original landscapes. Indeed, in many cases the results have characterised new landscapes.

Many governmental organisations have been involved in these transformations, e.g., the Bureau of Reclamation in the United States, or the Instituto Nacional de Colonización and later the Instituto de Reforma y Desarrollo Agrario in Spain. This has led to very large areas being affected by topographic change, and often changes in the division of land as it has become more regular. The landscapes affected have also seen the appearance of access routes and water transport systems (pipes, channels, drainage channels etc.). The latest irrigation systems (e.g., spraying, and later drip irrigation), however, avoid topographic change. They have no need of levelling or terracing, although they do introduce their own elements into the landscape, such as distribution pipes and spraying/sprinkling systems etc. (Zomeni et al., 2008).

Pivot irrigation systems generate characteristic circular shapes in land parcels; these are quite visible when viewed from above. This leads to a very particular kind of landscape with circles of colour crossed by wheeled distribution systems involving elevated tubes and their surrounding 'water clouds'.

Water-proofed pools have had an effect on the landscape of southern Spain. These structures have become ever more common since they allow irrigation when required - or at least without the timetabling restrictions little liked by farmers. In a sense these structures are the descendants the water tanks or aljibes used by the Moors in their irrigation systems. These small pools are usually cut and fill constructions on slopes, covered in a layer of dark plastic. They therefore mostly change the orography and colour of the landscape. In some areas they are now so common that they have begun to characterise the landscape and to actually affect the microclimate, flora and fauna.

The same areas where these pools are found are home to hectare after hectare of flexible plastic-covered greenhouses, the most obvious anthropic alteration of the landscape. Although these cannot be considered water-engineering constructions in the strict sense, their presence is a direct consequence of irrigation water being available. They can, therefore, be considered part of the irrigation landscape. The resulting landscape is often referred to as a sea of plastic (figure 7). Different observers take different views; some look upon this change with great admiration, others with profound rejection. While the discussion regarding the impact of this type of agriculture on the landscape continues, there is clearly room for improvement in the collection and treatment of the waste plastic it produces (Picuno et al. 2011). 


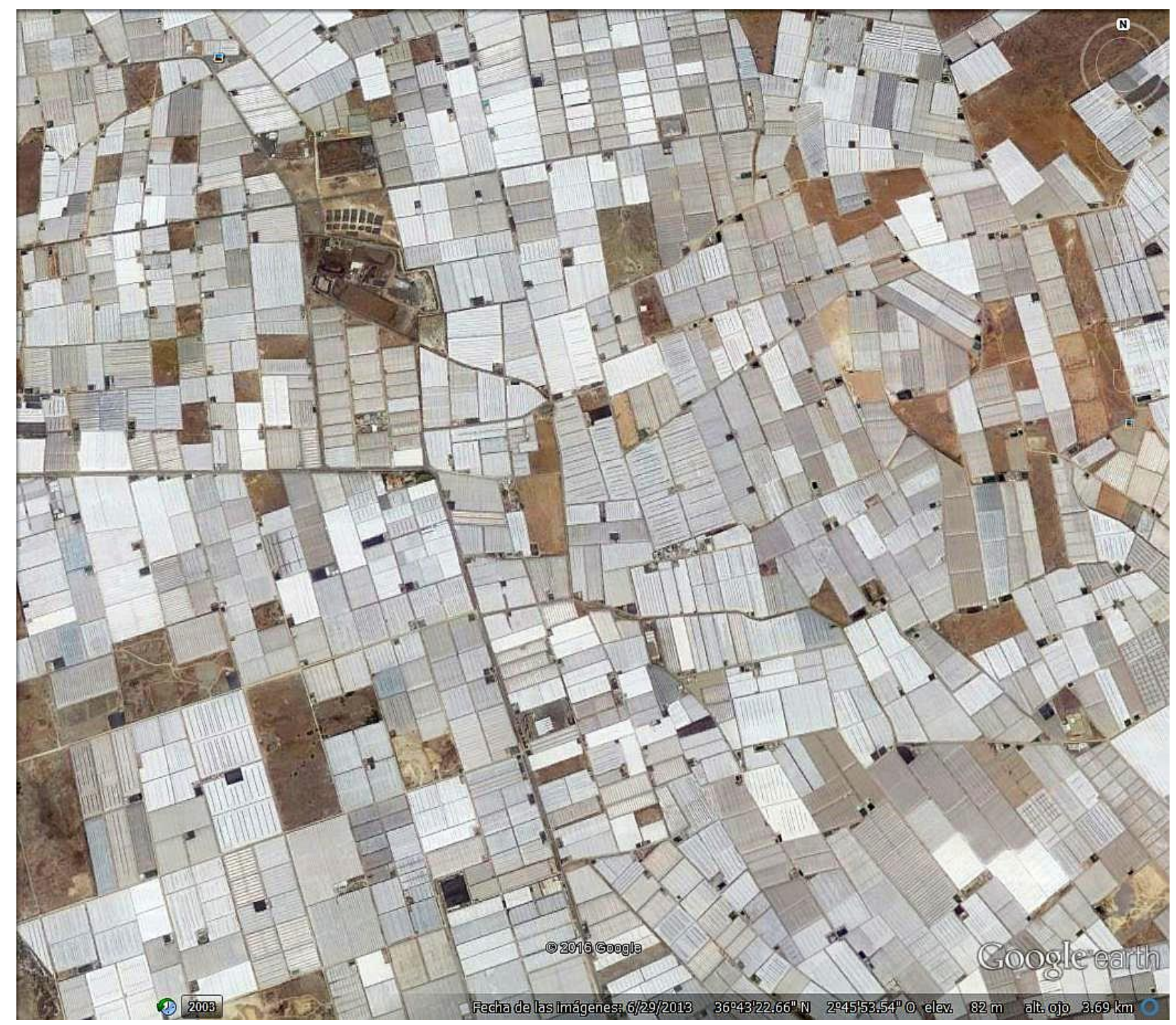

Fig 7. "Plastic sea" in Almería (Spain) (Google Earth image).

The greatest transformation of the landscape however, is that associated with its vegetation. The availability of water outside of the natural rainy season allows the cultivation of exotic plants - and the invasion of others that displace native species. Plants can now grow at times when once they could not. This change, which has occurred over great areas, and generally quite quickly, is associated with changes in colour and textures, but all the senses can be affected. The ochres, yellows and dark greens of dry plants that persisted for long periods on once rainfed land may change for more intense greens or take on much more colour as plants flower. The wet ground may also reflect a different palette. The uniform texture of dryland cereal crops, which changes over the year but hardly at all from one field to the next, becomes more rough and varied where irrigation is supplied. No longer need all fields grow the same crop. Indeed, it is now common to see short plants, such as beet and alfalfa, growing alongside medium sized winter barley or wheat, and tall plants such as maize, sorghum and even fruit trees. However, if there is no variation in the crops grown, irrigation can make the land appear uniform and monotonous. The sound of an irrigated landscape can also be different to that of a rainfed area, the result of changes in the fauna that lives in the area, and of the microclimate. The sound of the wind can change, and certainly the sound of the water itself marks a difference. In fact all the sensations perceived in rainfed land, both during the growing and resting phase, differ to those felt in an irrigated area. These differences, of course, are noticed more strongly by those live in changing drylands than they are by visiting urbanites who switch between one type of landscape and the other. 
While those who live in dry areas generally believe the changes in perception of the landscape brought about by irrigation to be positive - a consequence of having lived 'without water' - those who live in wetter areas may not feel the same way. They may see this converted land as too anthropic, and judge rainfed land to look more natural.

It would be of interest to study the border areas between rainfed and irrigated lands and to establish between and after comparisons that would allow future actions to improve respect for, and the conservation of, the landscape.

Later developments in human history, the extension of cultivated lands, stock raising, urbanisation and tourism have favoured the draining of wetlands.

Many lagoons and swamps have been drained in Spain, radically changing the landscape. The Nava de Campos Lagoon in Palencia is a case in point. Its draining was first proposed during the time of Ferdinand and Isabella, and the idea resurfaced numerous times until it was eventually acted upon in 1835. For economic reasons the infrastructure involved was later destroyed, but the area was once again drained in the 1950s. However, the wetlands were again recovered to some extent in the 1990s (Sánchez-González et al., 2016). Another important example is the wetland at Antela in Orense. One of the largest in Spain, it was drained some 50 years ago to improve the health of those living in the area and to bring more land under agriculture. However, the greatest draining of a wetland in Spain was that of the Guadalquivir marshes. Three factors working together over the last 200 years produced an important change in the landscape: the dredging of the river to make it navigable (which changed the way in which floods occurred and thus how sediments were deposited), irrigation (with its network of drainage canals and which lowered the groundwater level, drying out large areas), and urban pressure (Zorrilla-Miras et al., 2014).

Sometimes, wetlands can dry out indirectly as an undesired consequence of some other activity. In the upper reaches of the Guadiana Basin, regulation of the river and affluents via the use of dams, and the extraction of water by pumping, have led to the large scale drying of the area's wetlands. These areas were very important from a cultural, biological and landscape standpoint; indeed, they include the Ojos del Guadiana and Tablas de Daimiel wetlands. The same happened to the Marjal de Peñíscola wetland in Castellón.

Fortunately, these wetlands are today recovering as part of efforts to favour biodiversity and restore the balance of natural phenomena. The RAMSAR convention has been protecting wetlands since 1971; Spain became a signatory in 1982. Today there are 38 protected wetlands throughout the country (Koester, 2014).

\section{Methodology}

Environmental Impact Assessment of irrigation projects and also the works and constructions described in the previous section is strongly regulated by laws and rules in European countries and particularly in Spain. So, in this section the great number of regulations and some details of their coverage are presented.

Water is an important, trans-border, environmental factor: rivers and water bodies often cross neighbouring administrative territories. Spain is a party to international conventions such as the Convention on Environmental Impact Assessment signed in Espoo in 1991, and the socalled Protocol on Strategic Environmental Assessment to the Convention on Environmental Impact Assessment in a Transboundary Context, signed in Kiev 2003 (PSEACEIATC, 2003).

Many of peninsular Spain's large rivers that meet the Atlantic have crossed Portugal. The Protocol of Behaviour observed by the two countries, to be followed when making environmental assessments of plans, programs and projects with cross-border effects, was signed in 2008.

In Spain, environmental legislation has been updated in line with European directives. The Spanish Ministry of Agriculture, Fisheries and Food has produced support guidelines for irrigation engineering projects in order that they meet environmental requirements (San Sebastián et al., 2007). 
Royal Decree (Real Decreto) 1131/1988, approved legislation for the execution of Royal Legislative Decree 1302/1986 Regarding Environmental Impact. This was then amplified to the planning level by Law 9/2006, which regulated certain plans and programs and their effect on the environment. Modification and amendment continued until the establishment of the current Law 21/2013 Regarding Environmental Assessment.

The latter law considers water and the landscape as two factors of the environment and establishes the rules to be followed for the environmental assessment of plans, programs (strategic environmental assessment) and projects (assessment of environmental impact) that might have significant environmental effects. Its aim is to guarantee environmental protection and promote sustainable development. When a project may directly or indirectly affect a Natura 2000 area, a section must be included on the assessment of its repercussions on the affected area, bearing in mind the conservation aims of that area.

The annexes that accompany Law 21/2013 contain lists of projects subject to different levels of environmental assessment depending on their size. Annex I covers projects subject to 'ordinary' environmental assessment, and includes:

a) Dams/reservoirs and other installations designed to retain or store a new or additional water volume equal to or greater than $10 \mathrm{hm}^{3}$.

b) Projects for the extraction of ground water or the artificial recharging of aquifers, if the annual water volume extracted or provided is equal to or greater than $10 \mathrm{hm}^{3}$.

c) Water transfer between river basins, except for transfers of water for human use by pipeline, in any of the following instances:

- 1. when the transfer aims to avoid a possible water scarcity and involves over $100 \mathrm{hm}^{3}$ per year.

- 2. when the mean flow from the donor basin is greater than $2000 \mathrm{hm}^{3} / y e a r$ and the volume of water transferred is $>5 \%$ of this quantity.

d) Wastewater treatment plants for dealing with populations of $>150000$.

Also included are projects executed in protected areas, Natura 2000 areas, and internationally protected areas according to Law 42/2007 regarding Natural Heritage and Biodiversity, specifically projects draining or bringing under irrigation areas of $>10$ ha.

Annex II, which covers projects subject to 'simplified' environmental assessment, includes water management projects for agriculture, such as:

- 1 Consolidation and improvement of irrigation of areas $>100$ ha (projects not included in Annex I).

- 2 Projects draining or bringing under irrigation areas of $>10$ ha.

It also covers installations for intensive aquaculture with a production capacity of $>500$ tonnes/year, and any project that envisages a change in land use affecting 50 ha or more.

With respect to water engineering and management Annex II covers:

a) The extraction of ground water or the recharging of aquifers (not included in Annex I) when the volume of water is greater than 1 but under $10 \mathrm{hm}^{3} /$ year.

b) Water transfer between river basins when the volume transferred is over $5 \mathrm{hm}^{3} /$ year and not included in Annex I.

Not included are projects for the pipeline transfer of water for human consumption, or the direct use of recycled waste water.

c) Channelling projects and projects for the defence of watercourse channels and banks over $5 \mathrm{~km}$ in length. Those projects designed to prevent risks to urban areas are not included.

d) Waste water treatment plants for populations of 10 000-150 000 people. 
e) Water desalination plants with a new or additional capacity of $>3000 \mathrm{~m}^{3} /$ day .

f) Long distance water conduction pipelines with a diameter of $>800 \mathrm{~mm}$ and a length of $>40 \mathrm{~km}$ (projects not included in Annex I).

g) Dams/reservoirs and other installations for retaining or storing water as long as one of the following conditions are met:

- 1. the project involves large dams/reservoirs as defined in the 'Reglamento técnico sobre Seguridad de Presas y Embalses' approved on 12th March 1996, when not included under Annex I.

- 2. the project involves other installations designed for retaining water not included above, with a new or additional capacity of $>200000 \mathrm{~m}^{3}$.

Annex II also covers the following projects when undertaken in protected areas, Natura 2000 areas, and internationally protected areas according to Law 42/2007 regarding Natural Heritage and Biodiversity:

a) Waste water treatment plants that might cause negative ecological changes.

b) Channelling projects and projects for the defence of watercourses that might cause negative ecological changes.

c) Any project that entails a change in land use affecting 10 ha or more.

Annex III provides the criteria to determine whether a project covered by Annex II should in fact be subject to 'ordinary' environmental assessment. These criteria take into account whether a project is to be executed in an area of particular sensitivity that might be negatively affected, e.g., wetlands, or landscapes of historic, cultural or archaeological importance (some under irrigation).

The Irrigators' Tribunals of Spain's Mediterranean area are legal institutions involved in water management that go back to the time of Al Andalus (9-13 ${ }^{\text {th }}$ centuries). The two most important, the Consejo de Hombres Buenos de la Huerta de Murcia and the Tribunal de las Aguas de la Huerta de Valencia, are legally recognised bodies, which in 2009 were also recognised by UNESCO as Intangible Cultural Heritage (Ruiz \& Yáñez, 2014).

\section{Results}

After a number of years of application of the rules and standards described in the previous section, the authors propose a list of landscape descriptors to be considered in irrigation engineering.

The following lines provide a list of landscape descriptors with special reference to the presence of water. These are divided into blocks representing an engineering viewpoint:

- Surface water and its natural consequences on the landscape (natural water landscapes)

- Surface or subterranean water captured by Man and used for consumption, to supply irrigation, and used in other ways, and the landscapes this generates (anthropic water landscapes)

Descriptors associated with natural water landscapes may also be applicable to anthropic water landscapes, but the latter landscape always contains elements (installations, etc.) not present in the former (Fuentes, 2010, García \& Ayuga, 2007).

Natural water landscapes

- Orography

Surface. The surface of the land is analysed from a visual and perceptual standpoint.

Colour. This refers to the colour of bare ground and rock.

Roughness. The roughness perceived by an observer in areas not covered by vegetation. 
Uniformity. A visual field may be uniform in terms of colour and roughness or show some variation, be a mosaic, or have predominantly different areas etc.

Relief. The relief within the visual field.

Slopes. The slopes within the visual field, their steepness, position, and whether the slopes are uniform or differ from one another.

Unique elements (hills, cliffs etc.). All unique elements, irrespective of size.

Coverage. The parts of the terrain covered and their composition.

Vegetation. The percentage area covered by vegetation.

Water. The percentage or mass of water and water flows.

Anthropic elements (roads, buildings etc.). The percentage area covered by constructions.

- Vegetation

Type

Size (herbaceous, woody). Differences should be drawn between herbaceous, bushy, understory, small trees and tall trees etc.

Crown type. Rounded, pointy, weeping etc.

Leaf permanence. Deciduous, evergreen, mixed.

Density. The percentage of each type in the visual field.

Very dense.

Medium

Scant

Uniqueness.

Unique elements. Trees and shrubs catalogued as being of historic or cultural interest, threatened and protected species.

Unique vegetation spots. Patches of vegetation that are protected or special owing to their uniqueness or because they give shelter to animals that are threatened or protected.

Lake shores and river banks. Riparian vegetation and the percentage it occupies within the visual field.

Diversity. The added value provided by the variation in the vegetation.

Variation in species.

Variation in form and colour.

Uniformity.

Distribution. The types of grouping of the vegetation and its percentages in the field of view.

Linear. A marked tendency of the vegetation to follow a line across the terrain whether for natural or anthropic reasons.

Superficial. A tendency for the vegetation grouping to cover a large area.

Disperse. Elements of isolated vegetation or small groupings extended over a wide area.

Regular. A formation of groupings that are similar caused by irrigation, land parcelling or construction.

- Water

Type

Surface. Lakes, lagoons, reservoirs, etc.

Linear. Streams, canals, drainage channels etc. 
Discontinuous. Dry riverbeds that occasionally carry water or a mass of water caused by a rising groundwater level.

Disperse. Irregular surface appearance of water due a high groundwater level.

Appearance. The visual image and sensations caused by the water from the point of view of its composition and substances in suspension.

Clean

Dirty

Crystalline

Movement

Stagnant. Still surface waters or a non-flowing watercourse (or not appreciable to the eye)

Mild flowing. Some movement but no waves or splashing.

Strong flowing. Turbulent flow and splashing.

Rapids. Turbulent flow making sound and strong splashing.

Uniqueness. Unique elements of watercourses.

Waterfalls

Springs

The birth of rivers

Meanders

Amplitude or importance in the setting. Percentage area covered by water. Attention drawing power.

- Non-visual sensations

Sound

Birdsong

Sounds of other animals

The wind in the vegetation

The movement of water

Smells

Smell of the vegetation

Small of the earth

Environment

Damp

Cool

Sultry

Windy

Light

Dark

Anthropic water landscapes

In addition to the above, this category includes:

- Water capture infrastructure. Types, sizes, number, focus in the landscape.

Wells

River water capture structures

Weirs

- Storage infrastructure. Types, sizes, number, focus in the landscape. 
Dams

Sown earthen dam

Bare earthen dam

Masonry or rock dam

Concrete dam

Reservoirs. Types, sizes, number, focus in the landscape.

Waterproofed with plastic

Waterproofed with other materials

No waterproofing

Tanks. Types, sizes, number, focus in the landscape.

Metallic

Concrete

Brick

Towers

-Transport infrastructure. Types, sizes, number, length, direction in which the filed of view is crossed, focus in the landscape.

Visible pipes

Metallic

Concrete or fibrocement

Plastic

Canales and water channels

Dug into the soil

Stone lined

Made with concrete, fibrocement or brick

Siphons

- Application systems. Types, sizes, number, focus in the landscape.

Raised sprinklers

Low sprinklers

Pivot

Irrigation cannons

Localized irrigation

Furrow irrigation

Rectangular surface irrigation

- Drains. Types, sizes, number, focus in the landscape.

Superficial drainage channels dug into the soil

Lined superficial drainage channels

- Auxiliary infrastructure. Types, sizes, number, focus in the landscape.

Pump buildings

Service roads. Length, direction taken, form (straight, winding, etc.), width, drops in level etc.

Filtering installations

Meters

Valve equipment 


\section{Conclusions}

- The Mediterranean Basin has hot, dry summers that make agriculture difficult without irrigation.

- Irrigation has a long history all over the world. In Spain it is not just an economic necessity but a cultural tradition.

- The water engineering infrastructure needed for irrigation can modify the landscape in different ways and over large areas.

- Irrigation can lead to changes in the configuration of a territory, including its topography and vegetation, and can give rise to characteristic landscapes.

- Modern-day environmental legislation strongly conditions future projects.

- Descriptors for landscapes affected by irrigation engineering are provided. These help managers consider the landscape implications of their actions and encourage them to adhere to environmental legislation.

References

[1] Cañas, I., Ayuga, E. \& Ayuga, F. (2009). A contribution to the assessment of scenic quality of landscapes based on preferences expressed by the public. Land Use Policy 26(4), 1173-1181. Doi: 10.1016/j.landusepol.2009.02.007.

[2] Cañas, J. R. \& Pérez, M. M. (2007). La ingeniería y la gestión del agua de riego en AlAndalus. Ingeniería del agua 14(3), 223-236. Doi: 10.4995/ia.2007.2914.

[3] Díaz-Palacios-Sisternes, S., Ayuga, F. \& García, A. I. (2014). A method for detecting and describing land use transformations: An examination of Madrid's southern urban-rural gradient between 1990 and 2006. Cities 40, 99-110. Doi: 10.1016/j.cities.2014.03.010.

[4] Doyle, M. W., Harbor, J. M. \& Stanley, E. H. (2003). Toward policies and decision-making for dam removal. Environmental Management, 31(4), 0453-0465. Doi: 10.1007/s00267002-2819-z.

[5] Everard, M. (2013). The Hydropolitics of Dams: Engineering or Ecosystems? London: Zed books.

[6] Fahlbusch, H. (2009). Early dams. Proceedings of the Institution of Civil EngineersEngineering History and Heritage 162(1), 13-18. Doi: 10.1680/ehh2009.162.1.13.

[7] Fuentes, J. M. (2010). Methodological bases for documenting and reusing vernacular farm architecture. Journal of Cultural Heritage 11(2), 119-129. Doi: 10.1016/j.culher.2009.03.004.

[8] Galili, E., Weinstein-Evron, M., Hershkovitz, I., Gopher, A., Kislev, M., Lernau, O., KolskaHorwitz, L. \& Lernaut, H. (1993). Atlit-Yam: A prehistoric site on the sea floor off the Israeli coast. Journal of Field Archaeology 20(2), 133-157.

[9] García, A. I. \& Ayuga, F. (2007). Reuse of abandoned buildings and the rural landscape: The situation in Spain. Transactions of the ASABE 50(4), 1383-1394.

[10] García-Asensio, J. M. \& Cañas, I. (2001). La valoración del paisaje. In F. Ayuga, ed. Gestión Sostenible de Paisajes Rurales. Técnicas e Ingeniería. Madrid: Fundación Alfonso Martín Escudero.

[11] García-Asensio, J. M. \& San Sebastián, J. (2006). Los paisajes españoles en la modernización del regadío. Comunicación Técnica. Madrid: Fundación CONAMA.

[12] Helguera Quijada, J., García Tapia, N. \& Molinero Hernando, F. (1988). El canal de Castilla. Valladolid: Junta de Castilla y León. 
[13] Hill, D. (2013). A history of engineering in classical and medieval times. London: Routledge.

[14] Kamash, Z. (2012). Irrigation technology, society and environment in the Roman Near East. Journal of arid environments, 86, 65-74. Doi: 10.1016/j.jaridenv.2012.02.002.

[15] Koester, V. (2014). The Ramsar Convention. Environmental Policy and Law 44(1/2), 100110.

[16] Mata Olmo, R. \& Sanz Herraiz, C. (2003). Atlas de los paisajes de España. Madrid: Ministerio de Medio Ambiente.

[17] Ministerio de Agricultura, Pesca y Alimentación - MAPA, 2001. Plan Nacional de Regadíos - Horizonte 2008. Políticas y directrices. Ed. Secretaría General de Agricultura y Alimentación, Dirección General de Desarrollo Rural. España.

[18] Olmo, R. M. \& Muñoz, S. F. (2004). La Huerta de Murcia: landscape guidelines for a peri-urban territory. Landscape Research 29(4), 385-397. Doi: $10.1080 / 0142639042000289028$.

[19] Parra, M. A. \& Barranco, J. C. C. (2003). Dams from the Roman era in Spain: analysis of design forms. In Proceedings of the First International Congress on Construction History: Madrid, 20 $0^{\text {th }}-24^{\text {th }}$ January 2003 (pp. 243-257). Valladolid: Instituto Juan de Herrera.

[20] Picuno, P., Tortora, A. \& Capobianco, R. L. (2011). Analysis of plasticulture landscapes in Southern Italy through remote sensing and solid modelling techniques. Landscape and urban planning 100(1/2), 45-56. Doi: 10.1016/j.landurbplan.2010.11.008.

[21] PSEACEIATC, Protocol on Strategic Environmental Assessment to the Convention on Environmental Impact Assessment in a Transboundary Context, Kiev 2003. Geneva, United Nations Economic Commission for Europe (UNECE), 2003 (http://www.unece.org/env/eia/sea_protocol.htm).

[22] Rojas-Sola, J. I. \& López-García, R. (2007). Engineering graphics and watermills: ancient technology in Spain. Renewable energy 32 (12), 2019-2033. Doi: 10.1016/j.renene.2006.10.013.

[23] Ruiz, J. C. \& Yáñez, C. M. (2014). El patrimonio agrario: definición, caracterización y representatividad en el ámbito de la UNESCO. Boletín de la Asociación de Geógrafos Españoles 66, 105-124.

[24] San Sebastián, J., García-Asensio, J. M., Hidalgo, M. \& Ajo, M. J. (2007). Guía sobre Evaluación de Impacto Ambiental de Regadío. Madrid: Ministerio de Agricultura, Pesca y Alimentación.

[25] Sánchez-González, S. M., Martínez-Alegría, R., \& Taboada, J. (2016). Modelling wetland change in Spain's Tierra de Campos district. Wetlands Ecology and Management 24(4), 399-410. Doi: 10.1007/s11273-015-9463-x.

[26] Subias, E., Fiz, I. \& Cuesta, R. (2013). The Middle Nile Valley: Elements in an approach to the structuring of the landscape from the Greco-Roman era to the nineteenth century. Quaternary International 312, 27-44. Doi: 10.1016/j.quaint.2013.08.027.

[27] Wilkinson, T. J. \& Rayne, L. (2014). Hydraulic Systems in the Middle East. In Encyclopaedia of the History of Science, technology, and medicine in Non-Western Cultures (2244-2263). Berlin: Springer. Doi: 10.1007/978-94-007-7747-7_10228.

[28] Zomeni, M., Tzanopoulos, J. \& Pantis, J. D. (2008). Historical analysis of landscape change using remote sensing techniques: An explanatory tool for agricultural transformation in Greek rural areas. Landscape and urban planning, 86(1), 38-46. Doi: 10.1016/j.landurbplan.2007.12.006.

[29] Zorrilla-Miras, P., Palomo, I., Gómez-Baggethun, E., Martín-López, B., Lomas, P. L. \& Montes, C. (2014). Effects of land-use change on wetland ecosystem services: A case 
study in the Doñana marshes (SW Spain). Landscape and Urban Planning, 122, 160-174. Doi: 10.1016/j.landurbplan.2013.09.013. 